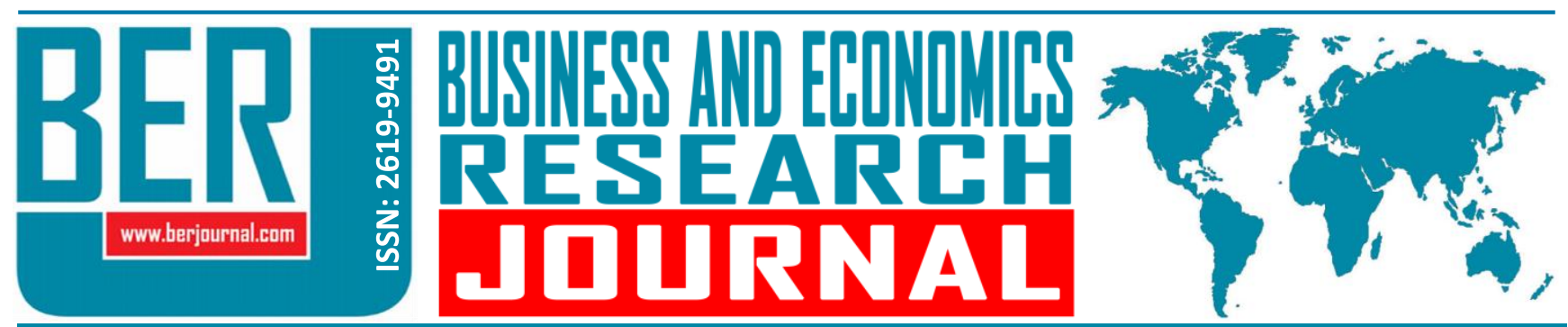

Business and Economics Research Journal Vol. 11, No. 1, 2020, pp. 169-185 doi: 10.20409/berj.2020.243

\section{Bankacılık Sektöründe Sermaye Yeterlilik Rasyosunu Belirleyen Faktörlerin Analizi ${ }^{1}$}

\author{
Fatma Citak ${ }^{\mathrm{a}}$, Ilkut Elif Kandil Goker ${ }^{\mathrm{b}}$
}

Öz: Üstlenmiş oldukları aracılık faaliyeti nedeniyle finansal sistemin en temel unsuru olarak kabul edilen bankaların risk ve karlılık yönetiminde, sermaye yeterlilik rasyosu önemli bir gösterge olarak kabul edilmektedir. Türkiye, tecrübe etmiş olduğu finansal krizler neticesinde bankaların sermaye yapılarına yönelik pek çok düzenleme gerçekleştirmiştir. 2006 yılından bu yana Basel kriterlerinin belirlemiş olduğu \%8 standart rasyo değerinin üzerinde bir asgari sermaye yeterlilik rasyosu (\%12) ile bankacılık sisteminin sağlamlaştırılması amaçlanmaktadır. Bu anlamda, risk ve karlılık yönetiminin önemli bir aracı olarak görülen sermaye yeterlilik rasyosunun belirlenmesinde etkisi olan faktörlerin tespit edilmesi önem arz etmektedir. Türkiye'de faaliyet gösteren ve finansal verilerine kesintisiz olarak ulaşılabilen mevduat bankaları üzerinde yapılan çalışmada 2002-2017 dönemine ait veriler kullanılmış ve panel veri analizi uygulanmıştır. Elde edilen bulgulara göre sermaye yeterlilik rasyosu ile bankaların toplam aktif büyüklüğü, mevduat/toplam aktif oranı, kredi/toplam aktif oranı, faiz marjı ve takipteki kredi/toplam kredi oranları arasında anlamlı bir ilişki olduğu tespit edilmiştir.

\section{Analysis of the Factors Determining the Capital Adequacy Ratio in the Banking Sector}

\begin{abstract}
Capital adequacy ratio is considered as an important indicator in the risk and profitability management of the banks, which are considered as the most fundamental element of the financial system due to their intermediation activities. Turkey has made many regulations for banks' capital structure after the experienced financial crisis. Since 2006, it is aimed to strengthen the banking system with a minimum capital adequacy ratio (12\%) above the standard ratio of $8 \%$ set by the Basel criteria. In this sense, it is important to identify the factors that affect the capital adequacy ratio, which is considered as an important tool of risk and profitability management The commercial banks operating in Turkey and whose complete financial data were available were used in the study and panel data analysis was conducted. According to the findings, it was determined that there is a significant relationship between the capital adequacy ratio and the banks' total asset size, deposit/total asset ratio, loan/total asset ratio, interest margin and non-performing loan/total loan ratios.
\end{abstract}

Anahtar Sözcükler: Sermaye Yeterlilik Rasyosu, Mevduat Bankaları, Türk Bankacılık Sektörü, Panel Veri Analizi

JEL: G21, L25

$\begin{array}{ll}\text { Geliş } & : 29 \text { Mayıs } 2019 \\ \begin{array}{l}\text { Düzeltme } \\ \text { Kabul }\end{array} & : \text { 06 Ağustos } 2019 \\ & : \text { 16 Ekim } 2019 \\ \text { Tür } & : \text { Araştırma }\end{array}$

Keywords: Capital Adequacy Ratio, Commercial Banks, Turkish Banking Sector, Panel Data Analysis

JEL: G21, L25

$\begin{array}{ll}\text { Received } & : 29 \text { May } 2019 \\ \text { Revised } & : 06 \text { August } 2019 \\ \text { Accepted } & : \text { 16 October } 2019 \\ \text { Type } & : \text { Research }\end{array}$

Type : Research

a Lecturer, Amasya University, Gümüşhacıköy Hasan Duman Vocational School, Finance, Banking and Insurance Program, Amasya, Turkiye, fatmacitak88@hotmail.com (ORCID ID:0000-0003-3276-4796)

b Asst. Prof., PhD., Kırıkkale University, The Faculty of Economics and Administrative Sciences, Department of Business Administration, Accounting And Finance, Kırıkkale, Turkiye, elifkandil@kku.tr (ORCID ID: 0000-0002-5290-3514) 


\section{Giriş}

Türk bankacılık sektöründe 1980 yılıyla birlikte finansal serbestleşme yönünde alınan kararlar ve yapılan düzenlemeler bankaların gerek aktif büyüklüğünde gerekse mevduat ve kredi hacminde önemli artışlar sağlamıştır. 1984 yılında döviz cinsinden mevduat açılmasının serbest bırakılması bankalarda kaynak artışını sağlamıştır. 1980-1990 döneminde ise, mevduatların krediye dönüşme oranının düştüğü gözlemlenmiştir. Bu nedenle reel sektörü fonlama fonksiyonunu yerine getiremeyen bankacılık sistemi, ekonomik büyümeye de yeterli desteği verememiştir. 1989 yılında sermaye hareketlerine yönelik alınan kararlar sonucunda ortaya çıkan kııılgan yapı, denetim ve düzenlemeye ilişkin zayıflıkları ve bankalar için risk algısı ve yönetimindeki eksikleri ortaya koymuştur. Sektörün tamamı yüksek faiz, kur ve likidite riski altında faaliyetlerini sürdürmek durumunda kalmıştır. Dolayısıyla 2000 ve 2001 yıllarında yaşanan finansal krizler yüksek riskler üstlenmiş olan bankacılık sektörünü önemli ölçüde küçültmüştür (Acar Balaylar ve Özdemir, 2018: 62-65). Yaşanan bu gelişmeler neticesinde bankacılık sektöründe yapısal düzenlemeler yapılmak üzere harekete geçilmiştir.

Bankalarla ilgili düzenleme ve denetleme yapmakla yetkili otoriteler, yapılan ilk düzenlemelerden itibaren sermayeyi banka iflaslarının önlenmesinde en önemli unsur olarak kabul etmişlerdir. Fakat bununla birlikte sermaye yeterliliğinin hesaplanmasında ülkelerde farklı yaklaşımların söz konusu olduğu görülmüştür. Bu durumun ortaya çıkarttı̆̆ı karmaşık yapı, riskleri ve belirsizlikleri büyüttüğü için risklerin tanımlanması ve gerekli önlemlerin alınması konusunda ortak görüş sağlanmasına ihtiyaç duyulmuştur (Ersoy, 2011: 55). Bankacılıkta risk kavramının her geçen gün öneminin artırıyor olması; Uluslararası Ödemeler Bankası (BISBank for International Settlements) tarafından düzenlenen Basel Komiteleri'nce sunulan değerlendirmelerin dikkate alınmasını zorunlu kılmaktadır. Bu değerlendirmelerde, bankaların risklilik durumlarına göre sahip olmaları tavsiye edilen asgari sermaye yükümlülükleri belirtilmektedir. Bununla birlikte; yaşanan çeşitli finansal krizler Basel Komitesinin değerlendirme kriterlerinin yenilenmesini gerektirmiş ve gerekli güncellenmeler düzenli olarak yapılmış ve yapılmaktadır (Yüksel Mermod ve Ceran, 2011: 35).

Basel Komitesince Temmuz 1988 yılında yayımlanan Basel I kriterinde; Sermaye Yeterlilik Rasyosu (SYR), "Toplam Sermaye/Kredi Riski" olarak belirlenmiş ve bankalar için bu oranın asgari \%8 olması gerektiği ifade edilmiştir. 1996 yılında yapılan revizyon ile sermaye yeterlilik rasyosu "Toplam Sermaye/ (Kredi Riski + Piyasa Riski)" olarak güncellenmiş, bununla birlikte \%8'lik asgari oran değiştirilmemiştir. 2004 yılında yayımlanan Basel Il kriteri, kredi riskini hesaplama yöntemini tamamen değiştirmiş, tüm risk sınıfları için kredi türü bazında risk ağırlığı belirlenmesi yerine ülkeler, bankalar, şirketler vb. risk sınıfları için müşterinin kredi değerliliğini ifade eden derecelendirme notu kullanılarak risk ağırlığının belirlenmesi veya bankaların kendi içsel derecelendirme modellerini kullanarak temerrüt olasıllğı, temerrüt halinde kayıp yüzdesi ve temerrüt anındaki risk tutarının belirlenmesi esas alınmıştır. Ayrıca operasyonel riskler için de bankaların sermaye bulundurmaları öngörülmüş ve sermaye yeterlilik rasyosu "Toplam Sermaye/(Kredi Riski + Piyasa Riski + Operasyonel Risk)" olarak güncellenmiştir (Erdoğan, 2014: 135). Bu değişim ve dönüşüm sürecinde ülkelerin tecrübe ettikleri finansal krizler, sistemin temelini oluşturan bankalar başta olmak üzere tüm finansal kuruluşlara gerekli durumlarda müdahale edilmesi gerektiğini ortaya koymuştur. Özellikle risklerin tespit edilebilmesi, finansal sistemden oluşan kırılganlıkların kontrol altında tutulması, dışsal şokların sisteme olan olumsuz etkilerinin azaltılması, mikro ve makro risklerin azaltılması gibi politikalara intiyaç duyulmuştur (Mizrahi ve Kandemir, 2018: 154-155). Bu nedenle 2010 yılı ile birlikte bankacılık sektöründe riskin en önemli göstergelerinden biri olan sermaye yeterlilik rasyosunun belirlenmesinde daha önce göz önünde bulundurulmayan çeşitli risk faktörleri de ele alınarak Basel III kriterleri geliştirilmiştir. Basel III kriterlerindeki amaç daha nitelikli ve niceliği artırılmış sermaye yapısı oluşturmak, sermaye tamponu oluşturmak, risk bazı olmayan kaldıraç oranını belirlemek ve likidite oranında düzenleme yapmaktır (Turguttopbaş, 2017: 750-751; Gürel, Bulgurcu Gürel ve Demir, 2012: 19-20). Bu çerçevede Basel III Kriterinin getirmiş olduğu yenilikler; ana sermaye ile ana sermaye içinde yer alan ve zararı karşılama düzeyi yüksek olan unsurlar olarak adlandırılan çekirdek sermaye içerisindeki en kaliteli kalemlerin hesaplamada kalmasının sağlanması, bankaların stres senaryoları ve tarihsel verilere dayanarak hesaplayacakları karşı taraf riski için ilave sermaye bulundurmalarının amaçlanması, ülke şartlarına ve tercihlerine bağlı olarak \%0-\%2,5 arasında sermaye tamponu uygulamasının getirilmesi, sermaye oranlarını destekleyici nitelikte olan şeffaf, basit, anlaşılır ve risk 
bazlı olmayan kaldıraç oranı oluşturulması ve Likidite Karşılama oranı ile bankaların uzun vadeli likidite yapısını ölçerek mevcut bilanço faaliyetlerinin uzun vadeli kaynaklarla fonlama gücünü ölçen net istikrarlı fonlama oranı eklenmesi şeklindedir (Turguttopbaş, 2017: 750-751; Gürel vd., 2012: 19-22; Mizrahi ve Kandemir, 2018: 156-157).

Türkiye'de, 1989 yılında kabul edilen Basel I Kriterleri kademeli bir geçiş süreciyle 1992'de tam olarak uygulanmaya başlanmıştır. Bu süreçte sermaye yeterlilik rasyosu 1989 yılında \%5, 1990'da \%6, 1991'de \%7 ve 1998 'de \%8 olarak uygulanmasına karar verilmiştir (Külahi, Tiryaki ve Yılmaz, 2013: 185). 2006 yılında ise Türkiye bankacılık sektörü, Basel II Kriterleri doğrultusunda sermaye yeterlilik rasyosu ölçüm yöntemini revize etmiştir. Basel III'de ise, sermayenin yeterliliği ile ilgili değişikliklerin yapılmasının nedeni, son finansal krizde banka bilançolarında sermaye olarak yansıtılan tutarların fonksiyonel olarak sermaye görevini yerine getirecek nitelikten uzak olmasının görülmesi olmuştur. Ayrıca, Türkiye'nin \%8 olarak kabul edilen sermaye yeterlilik oranına ilave olarak 2006 yılında asgari \%12'lik hedef oran belirlemesi kriz sürecinde Türk bankalarının sermaye sıkıntısı çekmemesinde en etkili önlemlerden biri olmuştur (BBDK, 2010: 12).Yapılan düzenlemeler neticesinde Türk bankacilık sektöründe yer alan bankaların ortalama sermaye yeterlilik rasyosunun gelişimi yıllar itibariyle Şekil 1'de gösterildiği gibi olmuştur (kpmg.com.tr, 15.12.2018).

Şekil 1. Türkiye Bankacılık Sektörü 2010-2018 Ortalama Sermaye Yeterlilik Rasyosu

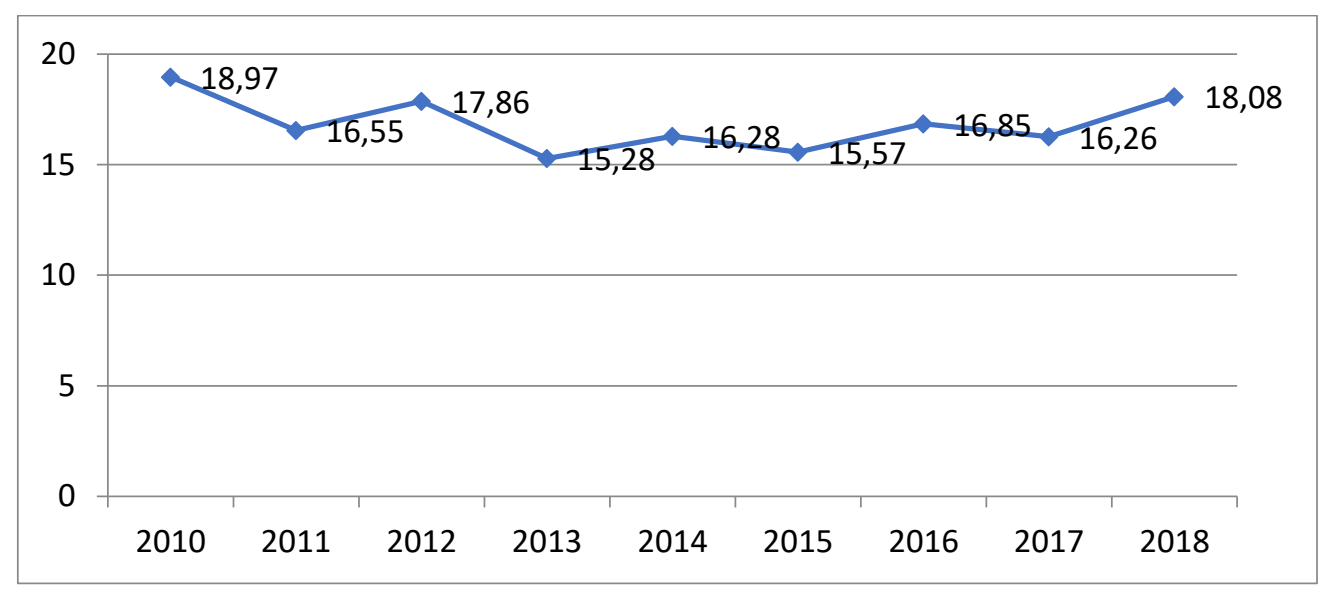

Kaynak: KPMG, 2018.

Şekilden de anlaşılacağı üzere Türk Bankacılık sektöründe ortalama sermaye yeterlilik rasyosu hem Basel III kriterlerinin oranının (\%8) hem de BDDK tarafından belirlenen oranın (\%12) üzerindedir.

Türkiye'nin özellikle 2000-2001 yıllarında tecrübe ettiği finansal kriz bankacılık sektörünün önemini ve bankacılık sektöründe risk yönetiminin önemini ortaya koymuştur. Bankaların finansal sistem içerisinde fon talep edenler ile fon arz edenler arasındaki aracılık faaliyetlerini kesintisiz yerine getirebilmesinde güçlü bir sermaye yapısına sahip olması hayati bir rol oynamaktadır. Bankalar için sermaye yapısının ne kadar güçlü ya da zayıf olduğunun bir göstergesi olan sermaye yeterlilik rasyosunun doğru belirlenmesi bu anlamda önem arz etmektedir. Yüksek belirlenmiş bir sermaye yeterlilik rasyosu, özkaynağın verimli alanlarda kullanılamaması nedeniyle düşük karlııkla; düşük belirlenmiş bir sermaye yeterlilik rasyosu ise pek çok risk faktörü dolayısıyla finansal başarısızlıkla sonuçlanabilmektedir. Bu çalışma bu anlamda sermaye yeterlilik rasyosunu etkileyen faktörlerin neler olduğunu tespit ederek; her bankanın kendisi için optimal bir sermaye yeterlilik rasyosu belirlerken göz önünde bulundurması gereken hususları ortaya koymayı amaçlamaktadır.

Giriş kısmında Türk bankacılık sektörü ve bankacılık sektöründe sermayenin önemi açıklanan çalışmanın ikinci kısmında sermaye yeterlilik rasyosunu etkileyen faktörlerin tespitine yönelik yapılan ulusal ve uluslararası çalışmalara yere verilmiştir. Üçüncü kısımda Türkiye bankacılık sektöründe faaliyet gösteren mevduat bankaları örnekleminde metodoloji, uygulama ve bulgular sunulmuş; sonuç kısmında bulgulara ilişkin değerlendirmelere yer verilmiştir. 


\section{Literatür Analizi}

Bankacılık alanıyla ilgili yapılan çalışmaların büyük bir kısmının inceleme konusu olan sermaye yeterlilik rasyosu, gerek bankaların karlılık, risklilik, likidite düzeylerine etkisi, gerekse optimal düzeyinin belirlenmesi boyutları ile incelenmiştir. Bu çalışmalardan birinde Kaya (2002), 1997-2000 döneminde Türk bankacılık sektöründe karılığın belirleyicilerini araştırmıştır. Çalışmada elde edilen bulgulara göre bankaların sermaye oranları ile aktif karlılı̆ı ve net faiz marjı arasında pozitif bir ilişki, özsermaye karlılığı ile arasında negatif bir ilişki tespit edilmiştir. Sermaye yeterlilik rasyosu ve karlııık arasındaki ilişkiyi ele aldığı çalışmasında Kılcı (2019) ise 1980-2017 dönemi için Türk bankacılık sektöründe yüksek sermaye oranının dış borçlanmaya olan ihtiyacı azalttığını; düşük sermaye oranının ise kaldıracı arttırarak iflas riskinin arttırdığını ve bankaların borçlanma maliyetini yükselttiğini, bu nedenle yüksek sermaye yeterlilik rasyosu ile karlılık arasında pozitif bir ilişki olması gerektiğini vurgulamıştır. Çalışmada Fourier ADL eşbütünleşme test sonuçlarına göre bankaların sermaye yeterlilikleri ile karlılıkları arasında uzun dönemde anlamlı bir ilişki olduğu tespit edilmiştir. Finansal krizin oluşumunun önlenmesi veya etkilerinin hafifletilmesinde sermaye düzenlemelerinin öneminin büyük olduğu vurgulanmıştır. Banka sermaye miktarı ile banka etkinliği arasında pozitif bir ilişki bulan Aysan ve Ceylan (2008) banka sermayesinin bir bankadaki mevduat miktarının artmasını sağlayan bir mevduat sigortası işlevi gördüğünü ifade etmiştir. Benzer şekilde Hassan ve Bashir (2003), 1994-2001 dönemi için dünyada islami bankacılık sektörü örnekleminde, Sayılgan ve Yıldırım (2009), 2002-2007 dönemi için Türk bankacilık sektörü örnekleminde, Tunay ve Silpar (2006), 1988-2004 dönemi için Türk bankacilık sektörü örnekleminde sermaye yeterliliği ile karlıık arasında bir pozitif ilişki olduğunu tespit etmiştir.

Sermaye yeterlilik rasyosunun belirlenmesinde etkili olan faktörlerin ortaya konulmasını amaçlayan çalışmalar da literatürde oldukça geniş bir yere sahiptir. Pek çok ülkede sermaye yeterlilik rasyosunu etkileyen mikro ve makro faktörleri tespit etmek üzere çeşitli çalışmalar yürütülmüştür.

Ahmad vd. (2008), Malezya bankacılık sektöründe faaliyet gösteren, 55 bankadan oluşan örneklem üzerinden 1995-2002 dönemi için ele aldıkları çalışmalarında takipteki kredi değişkenin sermaye yeterlilik rasyosunu pozitif etkilediğini, bununla birlikte banka büyüklüğünün negatif yönde etkilediğini tespit etmişlerdir.

Büyükşalvarcı ve Abdioğlu (2011), Türk bankacılık sektöründe faaliyet gösteren 24 ticari banka örneklemi üzerinde 2006-2010 dönemi için bankaların sermaye yeterlilik rasyosunu etkileyen faktörleri belirlemeyi amaçladıkları çalışmalarında bankaya özgü faktörlerin etkisine odaklanmışlardır. Banka büyüklüğü, mevduat, kredi, kredi kayıp karşılığı, likidite, karlıık, net faiz marjı ve finansal kaldıraç değişkenlerinin bağımsız değişken olarak dahil edildiği panel veri analizi sonuçlarına göre özkaynak karlılığı, aktif karlılı̆̆ı, kredi kayıp karşılığı değişkenlerinin sermaye yeterlilik rasyosunu pozitif yönde etkilerken; kredi, finansal kaldıraç değişkenlerinin ise negatif yönde etkilediği tespit edilmiştir.

Bokhari, Ali ve Sultan (2012), Pakistan bankacılık sektöründe faaliyet gösteren 12 Ticari Bankanın 2005-2009 dönemleri için bankaların sermaye yeterlilik rasyosunu etkileyen faktörleri belirlemeyi amaçladıkları çalışmalarında, mevduat payı, portföy riski ve özkaynak karlılığı değişkenlerinin negatif etkilediği tespit edilmiştir.

Romdhane (2012), Tunus bankacılık sektöründe faaliyet gösteren 12 ticari banka örneklemi üzerinde 2002-2008 dönemi için bankaların sermaye yeterlilik rasyosunu etkileyen faktörleri belirlemeyi amaçlamıştır. Çalışmalarında sermaye yeterlilik rasyosunu kredi kayıp karşılığı olarak nitelendirilen risk faktörü, net faiz marjı, yapısal düzenleme baskısı değişkenlerinin pozitif yönde etkilediğini; sermaye maliyeti, vadeli mevduatların vadesiz mevduatlara oranı olarak ifade edilen mevduat oranları ve mevduat çıkışlarının mevduat girişlerine oranı olarak ifade edilen mevduat değişkenliğinin ise negatif yönde etkilediği tespit edilmiştir.

Dreca (2013) Bosna bankacılık sektöründe faaliyet gösteren 10 bankanın 2005-2010 dönemine ait finansal tablo verisini kullanarak sermaye yeterlilik rasyosunu etkileyen faktörleri analiz etmeyi amaçlamıştır. Gerçekleştirilen panel veri analizi sonuçlarına göre bankanın toplam varlık tutarı ile ifade edilen büyüklük değişkeninin, mevduatların toplam varlıklara oranı ile ifade edilen mevduat varlık oranı değişkeninin, 
kredilerin toplam varlıklara oranı ile ifade edilen kredi varlık oranı değişkeninin ve aktif karlılığı değişkeninin sermaye yeterlilik rasyosunu negatif etkilediğini; takipteki kredinin toplam krediye oranı alınarak belirlenen kredi kayıp karşılığı değişkeninin ve finansal kaldıraç değişkeninin pozitif yönde etkilediğini tespit etmiştir.

Al-tamimi ve Obedat (2013), Ürdün bankacllık sektöründe faaliyette bulunan ve borsada işlem gören 12 ticari banka örneklemi üzerinde 2000-2008 dönemi için sermaye yeterlilik rasyosunu etkileyen faktörleri belirlemeyi amaçladıkları çalışmalarında doğrusal panel veri analizini kullanmışlardır. Analiz sonuçlarına göre, likidite riski, aktif karlılı̆̆ı, özkaynak karlılığı ve faiz oranı riski değişkenlerinin sermaye yeterlilik rasyosunu pozitif etkilediği; varlık kazanç oranı değişkeninin ise negatif etkilediği tespit edilmiştir.

Abusharba, Triyuwono, İsmail ve Rahman (2013) Endonezya bankacılık sektöründe faaliyet gösteren 11 İslami Ticari Banka örneklemi üzerinde ele aldıkları çalışmalarında 2009-2011 dönemi için aktif karlıı̆̆ı ve likidite oranı değişkenlerinin sermaye yeterlilik rasyosunu pozitif etkilediği, aktif kalitesi değişkeninin ise negatif etkilediği tespit edilmiştir.

Bateni vd. (2014), İran bankacılık sektöründe faaliyet gösteren 18 banka örneklemi üzerinde 20062012 dönemi için bankaların sermaye yeterlilik rasyosunu etkileyen faktörleri belirlemeyi amaçladıkları çalışmalarında, kredilerin toplam varlıklara oranı, özkaynak karlılı̆ı ve aktif karlılığı değişkenlerinin sermaye yeterlilik rasyosunu pozitif yönde etkilediğini; banka büyüklüğü değişkeninin ise sermaye yeterlilik rasyosunu negatif yönde etkilediği tespit edilmiştir.

Polat ve Al-khalaf (2014) ise Suudi Arabistan Krallığında borsada işlem gören 10 bankanın verileri ile 2008-2012 dönemi için panel veri analiziyle bankaların sermaye yeterlilik rasyosunu etkileyen faktörleri tespit etmiştir. Analiz sonucunda banka büyüklüğü ve mevduat oranı değişkenlerinin sermaye yeterlilik rasyosunu negatif etkilediği, aktif karlılı̆ı değişkenlerinin sermaye yeterlilik rasyosunu pozitif yönde etkilediği tespit edilmiştir.

Nuviyanti ve Anggono (2014), Endonezya bankacılık sektöründe faaliyet gösteren 19 ticari banka örneklemi üzerinde 2008-2013 dönemi için bankaların sermaye yeterlilik rasyosunu etkileyen faktörleri analiz etmeyi amaçlamıştır. Panel veri analizi sonuçlarına göre, özkaynak karlıı̆ğı, kredi mevduat oranı ve faaliyet giderlerinin faaliyet gelirlerine oranı değişkenlerinin sermaye yeterlilik rasyosunu negatif etkilediğini; aktif karlılı̆ı ve takipteki kredi oranı değişkenlerinin sermaye yeterlilik rasyosunu pozitif yönde etkilediği tespit edilmiştir.

Alajmi ve Alqasem (2015), Kuveyt’te faaliyet gösteren 5 banka örneklemi üzerinde 2005-2013 dönemi için bankaların sermaye yeterlilik rasyosunu etkileyen faktörleri analiz etmeyi amaçlamıştır. Panel veri analizi sonuçlarına göre banka büyüklüğü ve aktif karlılığı değişkenlerinin sermaye yeterlilik rasyosunu negatif yönde etkilerken, mevduat oranı değişkeninin ise sermaye yeterlilik rasyosunu pozitif yönde etkilediği tespit edilmiştir.

Mekonnen(2015), Etiyopya bankacılık sektöründe faaliyet gösteren 19 banka için 2004-2013 döneminde sermaye yeterlilik rasyosunu etkileyen faktörleri analiz etmiş; banka büyüklüğü, aktif karlılı̆̆ ve mevduat oranı değişkenlerinin sermaye yeterlilik rasyosunu pozitif yönde etkilediğini; özkaynak karılığının ve net faiz marjı değişkenlerinin ise sermaye yeterlilik rasyosunu negatif yönde etkilediğini tespit etmiştir.

Banka büyüklüğünün sermaye yeterlilik rasyosunu pozitif yönde etkilediğini tespit eden bir başka çalışmada Klepczarek (2015), 2014 yılına ait 49 Avrupa bankası örneklemi üzerinde çalışmıştır. Banka büyüklüğüne ek olarak toplam varlıklar içerisinde risk ağırlıklı varlıkların payı ve kredilerin aktifler içerisindeki payının sermaye yeterlilik rasyosunu pozitif olarak etkilediğini tespit etmiştir.

El-Ansary ve Hafez (2015),Klepczarek (2015)'nin aksine banka büyüklüğünün sermaye yeterlilik rasyosunu negatif yönde etkilediğini öne sürmüştür. Mısır bankacılık sektöründe faaliyet gösteren 36 ticari banka örneklemi üzerinde 2003-2013 dönemi için sermaye yeterlilik rasyosunu etkileyen faktörleri belirlemeyi amaçlamışlardır. Elde ettikleri bulgular banka büyüklüğü ile sermaye yeterlilik oranı arasındaki negatif yönlü ilişkinin yanında likidite oranı, yönetim kalitesi ve kredi riski değişkenlerinin sermaye yeterlilik rasyosunu pozitif yönde etkilediği yönünde olmuştur. 
Irawan ve Anggono (2015) Endonezya'da BUKU 3 VE BUKU 4'te faaliyet gösteren banka örneklemi üzerinde 2005-2014 dönemi için panel veri analiziyle bankaların sermaye yeterlilik rasyosunu etkileyen faktörleri analiz etmişlerdir.Elde ettikleri bulgulara göre, net faiz marjı, kredi ve mevduat değişkenlerinin sermaye yeterlilik rasyosunu negatif etkilediği; aktif karlılı̆ı, banka büyüklüğü ve takipteki kredi oranı değişkenlerinin sermaye yeterlilik rasyosunu pozitif yönde etkilediği tespit edilmiştir.Benzer şekilde Shingkergji ve Hayseni (2015)'nin Arnavutluk bankacılık sektöründe faaliyet gösteren 3'ü devlet bankası 16 'sı özel banka olan toplam 19 banka örneklemi üzerinde 2007-2014 dönemi için sermaye yeterlilik rasyosunu etkileyen faktörleri analiz etmeyi amaçladıkları çalışmalarında takipteki kredi oranının, sermaye yeterlilik rasyosunu pozitif etkilediği tespit edilmiştir.

Aktaş, Açıkalın, Bakın ve Çelik (2015), Güney Doğu Avrupa Ülkelerinde faaliyet gösteren 71 Ticari Bankanın 2007-2012 dönemi için sermaye yeterlilik rasyosunu etkileyen faktörleri analiz etmeyi amaçlamıştır. Gerçekleştirilen doğrusal panel veri analizi sonuçlarına göre banka büyülüğü, finansal kaldıraç ve risk değişkenlerinin negatif etkilediğini; aktif karlıı̆̆ı, net faiz marjı ve likidite değişkenlerinin ise oranını pozitif yönde etkilediği tespit edilmiştir.

Masood ve Ansari (2016), Pakistan bankacılık sektöründe faaliyet gösteren 14 Ticari Bankanın 20082014 dönemleri için panel veri analizi yöntemi ile yaptıkları analiz sonucunda ise, toplam mevduatların toplam varıklara oranı, özsermayenin toplam aktife oranı değişkenlerinin sermaye yeterlilik rasyosunu pozitif yönde etkilediğini tespit etmişlerdir.

Thoa ve Anh (2017), Vietnam bankacılık sektöründe faaliyet gösteren 29 ticari bankanın 2011-2015 dönemleri üzerinde yaptığı analizde ise, kredi kayıp karşılığının ve aktif karlılı̆ın sermaye yeterlilik rasyosunu negatif etkilediği; net faiz marjı ve likidite değişkenlerinin ise oranını pozitif yönde etkilediği tespit edilmiştir.

Abba, Okwa, Soje ve Aikpitanyi (2018), Nijerya da faaliyet gösteren 12 bankanın 2005-2014 dönemleri için yaptıkları panel veri analizi sonucunda, sermaye yeterlilik rasyosunu risk ağırlıklı varlıkların, mevduat oranlarının ve aktif karlılı̆ı değişkenlerinin pozitif yönde etkilediğini; takipteki kredilerin toplam kredilere oranı olarak ifade edilen aktif kalitesi değişkenlerinin negatif etkilediğini tespit etmişlerdir.

Minh ve Nga (2018),Vietnam bankacılık sektöründe borsada işlem gören 10 ticari banka örneklemi üzerinde 2008-2016 dönemleri için sermaye yeterlilik rasyosunu etkileyen faktörleri belirlemeyi amaçladıkları çalışmalarında, mevduat oranlarının, aktif karlılı̆̆ı, özkaynak karlılığı ve büyüklük değişkenlerinin sermaye yeterlilik rasyosunu pozitif yönde etkilediğini tespit etmiştir.

Moussa (2018), Tunus bankacılık sektöründe faaliyet gösteren 18 banka örneklemi üzerinde 20002013 dönem için panel veri analizi yöntemi ile yaptıkları analiz sonucunda ise; aktif karlılığı, net faiz marjı, likidite oranı, enflasyon oranı, sermaye yapısına göre özel mülkiyet ve yabancı mülkiyet oranı değişkenlerinin sermaye yeterlilik rasyosunu pozitif etkilediğini tespit etmişlerdir.

Ulusal çalışmalara bakıldığında, uluslararası yazında olduğu gibi Türk bankacılık sektörü için de farklılaşan pek çok bulguya rastlamak mümkündür. Okuyan (2013), Türk bankacılık sektöründe faaliyet gösteren 23 banka örneklemi üzerinde 2002Ç4-2012Ç1 dönemi için bankaların sermaye yeterlilik rasyosunu etkileyen faktörleri incelediğinde sermaye yeterlilik rasyosunu risk, büyüklük, mevduat oranı ve kredi oran değişkenlerinin negatif; ekonomik büyüme ve aktif karlılığı değişkenlerinin ise pozitif yönde etkilediğini tespit etmiştir. Reis ve Kötüoğlu (2016) çalışmalarında, Türk Bankaları örneklemi üzerinde 2009Ç1-2015Ç4 dönemi için aktif karlıı̆̆ın, özkaynak karlılı̆ının, likiditenin ve Takipteki kredi/Toplam kredi değişkenlerinin sermaye yeterlilik rasyosunu pozitif yönde etkilediği tespit edilmiştir. Koç ve Karahan (2017), Türk bankacılık sektöründe faaliyet gösteren bankaların 2005-2015 dönemlerine ait verilerinin kullanıldığı çalışmalarında, finansal varlıkların toplam aktiflere oranı ile ifade edilen aktif kalitesinin, faiz dışı gelirlerin toplam aktiflere oranı olarak ifade edilen net faiz dışı gelirlerin, likiditenin ve aktif karlılı̆̆ı değişkenlerinin sermaye yeterlilik rasyosunu pozitif yönde etkilediğini tespit etmiştir. Afşar ve Karaçayır (2018) ise, Türk bankacılık sektöründe faaliyet gösteren 9 bankanın 2002Ç4-2017Ç1 dönemi için bankaların sermaye yeterlilik rasyosunu etkileyen faktörleri incelediklerinde, kredi oranı, mevduat oranı ve aktif büyüklüğü değişkenlerinin negatif etkilediğini; aktif karlılı̆ın sermaye yeterlilik rasyosunu pozitif yönde etkilediği tespit edilmiştir. Hazar vd. (2018), Türk 
bankacilık sektöründe faaliyet gösteren mevduat toplama yetkisine sahip 22 banka örneklemi üzerinde 20042015 dönemi için ele aldıkları çalışmalarında Path analizini kullanarak sermaye yeterlilik rasyosunu doğrudan ve dolaylı etkileyen faktörleri bulmayı amaçlamışlardır. Sermaye yeterlilik rasyosunun belirlenmesinde birinci finansal göstergenin kredi, sonrasında menkul değerler cüzdanı ve en son sırada da nazım hesaplar olduğunu tespit etmişlerdir. Özer ve Özer (2018), bankaların sermaye yeterlilik rasyosunu etkileyen faktörlerin banka grupları bazında değişip değişmediğini inceledikleri çalışmalarında büyüklük ve finansal istikrarın bütün banka gruplarında sermaye yeterliliğini pozitif yönde, finansal sıkıntının ise negatif yönde etkilediğini; likidite ve varlık yapısının sermaye yeterliliği üzerinde mevduat ve özel sermayeli bankalarda pozitif etkisi olduğunu tespit etmişlerdir.

Tablo 1. Literatür Özeti

\begin{tabular}{|c|c|c|c|c|}
\hline \multicolumn{5}{|l|}{ Uluslararası Liratür } \\
\hline Yazar & Ülke- Dönem & Örneklem & Model & Sonuçlar \\
\hline $\begin{array}{l}\text { Ahmad, Ariff ve Skully } \\
\text { (2008) }\end{array}$ & $\begin{array}{l}\text { Malezya } \\
1995-2002\end{array}$ & $\begin{array}{l}\text { Toplam } 55 \\
\text { Banka }\end{array}$ & $\begin{array}{l}\text { Panel Veri } \\
\text { Analizi }\end{array}$ & $\begin{array}{l}\text { Risk Alma Davranışı (+) } \\
\text { Risk Endeksi (+) } \\
\text { Takipteki Alacaklar (+) } \\
\text { Büyüklük (+) }\end{array}$ \\
\hline $\begin{array}{l}\text { Romdhane } \\
\text { (2012) }\end{array}$ & $\begin{array}{l}\text { Tunus } \\
2002-2008\end{array}$ & $\begin{array}{l}18 \text { Ticari } \\
\text { Banka }\end{array}$ & $\begin{array}{l}\text { Panel Veri } \\
\text { Analizi }\end{array}$ & $\begin{array}{l}\text { Faiz Marjı (+) } \\
\text { Risk (+) } \\
\text { Mevduat (+) } \\
\text { Yapısal Düzenleme Baskısı (+) } \\
\text { Sermaye Maliyeti (-) } \\
\text { Mevduat Oranı (-) } \\
\end{array}$ \\
\hline $\begin{array}{l}\text { Abusharba, Triyuwono, } \\
\text { İsmail ve Rahman } \\
\text { (2013) }\end{array}$ & $\begin{array}{l}\text { Endonezya } \\
\text { 2009-2011 }\end{array}$ & $\begin{array}{l}11 \text { İslami } \\
\text { Ticari Banka }\end{array}$ & $\begin{array}{l}\text { Panel Veri } \\
\text { Analizi }\end{array}$ & $\begin{array}{l}\text { Aktif Karlılık Oranı (+) } \\
\text { Likidite (+) } \\
\text { Varlık Kalitesi (-) }\end{array}$ \\
\hline $\begin{array}{l}\text { Bokhari, Ali ve Sultan } \\
\text { (2013) }\end{array}$ & $\begin{array}{l}\text { Pakistan } \\
\text { 2005-2009 }\end{array}$ & $\begin{array}{l}12 \text { Ticari } \\
\text { Banka }\end{array}$ & $\begin{array}{l}\text { Panel Veri } \\
\text { Analizi }\end{array}$ & $\begin{array}{l}\text { Mevduat Payı (-) } \\
\text { Portföy Riski (-) } \\
\text { Özkaynak Karlılığı (-) }\end{array}$ \\
\hline $\begin{array}{l}\text { Dreca } \\
\text { (2013) }\end{array}$ & $\begin{array}{l}\text { Bosna } \\
\text { 2005-2010 }\end{array}$ & 10 Banka & $\begin{array}{l}\text { Panel Veri } \\
\text { Analizi }\end{array}$ & $\begin{array}{l}\text { Büyüklük (-) } \\
\text { Mevduat Varlık Oranı (-) } \\
\text { Kredi Varlık Oranı (-) } \\
\text { Aktif Karlıık Oranı (-) } \\
\text { Kredi Kayıp Karşılığı (+) } \\
\text { Özkaynak Karlıığı (+) } \\
\text { Net Faiz Marjı (+) } \\
\text { Finansal Kaldıraç (+) }\end{array}$ \\
\hline $\begin{array}{l}\text { Al- Tamimi ve Obeidat } \\
\text { (2013) }\end{array}$ & $\begin{array}{l}\text { Ürdün } \\
\text { 2000-2008 }\end{array}$ & $\begin{array}{l}\text { Borsada İşlem } \\
\text { Gören } 12 \\
\text { Ticari Banka }\end{array}$ & $\begin{array}{l}\text { Doğrusal Panel } \\
\text { Veri Analizi }\end{array}$ & $\begin{array}{l}\text { Likidite Riski (+) } \\
\text { Aktif Karlılık Oranı (+) } \\
\text { Özkaynak Karlılığı (+) } \\
\text { Faiz Oranı Riski (+) } \\
\text { Varlık Kazanç Oranı (-) }\end{array}$ \\
\hline $\begin{array}{l}\text { Naviyanti ve Anggono } \\
\text { (2014) }\end{array}$ & $\begin{array}{l}\text { Endonezya } \\
\text { 2008-2013 }\end{array}$ & $\begin{array}{l}19 \text { Ticari } \\
\text { Banka }\end{array}$ & $\begin{array}{l}\text { Doğrusal Panel } \\
\text { Veri Analizi }\end{array}$ & $\begin{array}{l}\text { Faaliyet Gideri / Faaliyet Geliri (-) } \\
\text { Özkaynak Karlılığı (-) } \\
\text { Kredi Mevduat Oranı (-) } \\
\text { Takipteki Kredi Oranı (+) } \\
\text { Aktif Karlılık Oranı (+) }\end{array}$ \\
\hline $\begin{array}{l}\text { Bateni, Vakilifard ve Asghari } \\
\text { (2014) }\end{array}$ & $\begin{array}{l}\text { İran } \\
\text { 2006-2012 }\end{array}$ & $\begin{array}{l}18 \text { Banka } \\
\text { (8 Devlet, } 7 \\
\text { Özel, } 3 \\
\text { Tasarruf } \\
\text { Bankası) }\end{array}$ & $\begin{array}{l}\text { Panel Veri } \\
\text { Analizi }\end{array}$ & $\begin{array}{l}\text { Büyüklük (-) } \\
\text { Krediler/Toplam Varlıklar (+) } \\
\text { Özkaynak Karlıı̆ğı (+) } \\
\text { Aktif Karlılık Oranı (+) }\end{array}$ \\
\hline $\begin{array}{l}\text { Polat ve } \\
\text { Al-khalaf } \\
(2014)\end{array}$ & $\begin{array}{l}\text { Suudi } \\
\text { Arabistan } \\
\text { Kralığı } \\
2008-2012\end{array}$ & $\begin{array}{l}\text { Suudi } \\
\text { Arabistan } \\
\text { Borsasında } \\
\text { İşlem Gören } \\
10 \text { Banka }\end{array}$ & $\begin{array}{l}\text { Panel Veri } \\
\text { Analizi }\end{array}$ & $\begin{array}{l}\text { Mevduat Oranı (-) } \\
\text { Krediler / Toplam Varlıklar(-) } \\
\text { Aktif Karlılık Oranı (+) } \\
\text { Finansal Kaldıraç (+) } \\
\text { Büyüklük(+) }\end{array}$ \\
\hline
\end{tabular}


Tablo 1. Literatür Özeti (Devamı)

\begin{tabular}{|c|c|c|c|c|}
\hline \multicolumn{5}{|l|}{ Uluslararası Liratür } \\
\hline Yazar & Ülke- Dönem & Örneklem & Model & Sonuçlar \\
\hline $\begin{array}{l}\text { Irawan ve Anggono } \\
\text { (2015) }\end{array}$ & $\begin{array}{l}\text { Endonezya } \\
2005-2014\end{array}$ & $\begin{array}{l}\text { BUKU 3, } \\
\text { BUKU } 4\end{array}$ & $\begin{array}{l}\text { Panel Veri } \\
\text { Analizi }\end{array}$ & $\begin{array}{l}\text { Varlıklar (+) } \\
\text { Aktif Karlııı Oranı (+) } \\
\text { Takipteki Kredi Oranı (+) } \\
\text { Özkaynak Karlııı Oranı (-) } \\
\text { Net Faiz Marı (-) } \\
\text { Kredi (-) } \\
\text { Mevduat (-) }\end{array}$ \\
\hline $\begin{array}{l}\text { Mekonnen } \\
\text { (2015) }\end{array}$ & $\begin{array}{l}\text { Etiyopya } \\
2004-2013\end{array}$ & 19 Banka & $\begin{array}{l}\text { Panel Veri } \\
\text { Analizi }\end{array}$ & $\begin{array}{l}\text { Aktif Karlııı Oranı (+) } \\
\text { Mevduat Oranı (+) } \\
\text { Büyüklük (+) } \\
\text { Özkaynak Karlııı Oranı (-) } \\
\text { Net Faiz Marjı (-) }\end{array}$ \\
\hline $\begin{array}{l}\text { Alajmi ve Alqasem } \\
(2015)\end{array}$ & $\begin{array}{l}\text { Kuveyt } \\
2005-2013\end{array}$ & 5 Banka & Panel Veri & $\begin{array}{l}\text { Büyüklük (-), } \\
\text { Aktif Karlılık Oranı (-) } \\
\text { Mevduat Oranı (+) }\end{array}$ \\
\hline $\begin{array}{l}\text { Klepczarek } \\
(2015)\end{array}$ & $\begin{array}{l}\text { Polonya } \\
2014\end{array}$ & $\begin{array}{l}49 \text { Avrupa } \\
\text { Bankası }\end{array}$ & $\begin{array}{l}\text { Panel Veri } \\
\text { Analizi }\end{array}$ & $\begin{array}{l}\text { Büyüklük (+) } \\
\text { Toplam Varlıklar İçerisinde } \\
\text { Kredilerin Aktifler İçindeki Payı (+) }\end{array}$ \\
\hline $\begin{array}{l}\text { El-Ansary ve Hafez } \\
\text { (2015) }\end{array}$ & $\begin{array}{l}\text { Misır } \\
2003-2013\end{array}$ & $\begin{array}{l}36 \text { Ticari } \\
\text { Banka }\end{array}$ & $\begin{array}{l}\text { Regresyon } \\
\text { Analizi }\end{array}$ & $\begin{array}{l}\text { Likidite (+) } \\
\text { Yönetim Kalitesi (+) } \\
\text { Aktif Kalitesi (+) } \\
\text { Kredi Riski (+) } \\
\text { Banka Büyüklüğü (-) }\end{array}$ \\
\hline $\begin{array}{l}\text { Aktaş, Açıkalın, Bakın ve } \\
\text { Çelik } \\
\text { (2015) }\end{array}$ & $\begin{array}{l}\text { Güney Doğu } \\
\text { Avrupa } \\
\text { 2007-2012 }\end{array}$ & $\begin{array}{l}71 \text { Güney } \\
\text { Doğu Avrupa } \\
\text { Ülkeleri Ticari } \\
\text { Bankaları }\end{array}$ & $\begin{array}{l}\text { Doğrusal Panel } \\
\text { Veri Analizi }\end{array}$ & $\begin{array}{l}\text { Banka Büyüklüğü (-) } \\
\text { Finansal Kaldıraç (-) } \\
\text { Risk (-) } \\
\text { Aktif Karlııı Oranı (+) } \\
\text { Net Faiz Marjı (+) } \\
\text { Likidite (+) } \\
\end{array}$ \\
\hline $\begin{array}{l}\text { Shingjergji ve Hayseni } \\
(2015)\end{array}$ & $\begin{array}{l}\text { Arnavutluk } \\
\text { 2007-2014 }\end{array}$ & $\begin{array}{l}3 \text { Devlet } \\
\text { Bankası ve } \\
16 \text { Özel Banka }\end{array}$ & $\begin{array}{l}\text { Panel Veri } \\
\text { Analizi }\end{array}$ & $\begin{array}{l}\text { Takipteki Kredi Oranı (-) } \\
\text { Mevduat Oranı (-) } \\
\text { Özsermaye Çarpanı (-) } \\
\text { Banka Büyüklüğü (+) }\end{array}$ \\
\hline $\begin{array}{l}\text { Masood ve Ansari } \\
\text { (2016) }\end{array}$ & $\begin{array}{l}\text { Pakistan } \\
\text { 2008-2014 }\end{array}$ & $\begin{array}{l}14 \text { Pakistan } \\
\text { Ticari Banka }\end{array}$ & $\begin{array}{l}\text { Panel Veri } \\
\text { Analizi }\end{array}$ & $\begin{array}{l}\text { Kredi Kayıp Karşılığı (+) } \\
\text { Mevduat Aktif Oranı (+) } \\
\text { Özsermaye /Toplam Aktif (+) }\end{array}$ \\
\hline $\begin{array}{l}\text { Thoa ve Anh } \\
\text { (2017) }\end{array}$ & $\begin{array}{l}\text { Vietnam } \\
\text { 2011-2015 }\end{array}$ & $\begin{array}{l}29 \text { Ticari } \\
\text { Banka }\end{array}$ & $\begin{array}{l}\text { Panel Veri } \\
\text { Analizi }\end{array}$ & $\begin{array}{l}\text { Kredi Kayıp Karşılığı (-) } \\
\text { Aktif Karlılık Oranı (-) } \\
\text { Net Faiz Marjı (+) } \\
\text { Likidite (+) }\end{array}$ \\
\hline $\begin{array}{l}\text { Moussa } \\
(2018)\end{array}$ & $\begin{array}{l}\text { Tunus } \\
\text { 2000-2013 }\end{array}$ & $\begin{array}{l}18 \text { Tunus } \\
\text { Bankası }\end{array}$ & $\begin{array}{l}\text { Panel Veri } \\
\text { Analizi }\end{array}$ & $\begin{array}{l}\text { Aktif Karlılık Oranı (+) } \\
\text { Net Faiz Marjı (+) } \\
\text { Likidite (+) } \\
\text { Enflasyon Oranı (+) } \\
\text { Özel Mülkiyet (+) } \\
\text { Yabancı Mülkiyet (+) }\end{array}$ \\
\hline $\begin{array}{l}\text { Abba, Okwa, Soje ve } \\
\text { Aikpitanyi } \\
\text { (2018) }\end{array}$ & $\begin{array}{l}\text { Nijerya } \\
2005-2014\end{array}$ & $\begin{array}{l}12 \text { Mevduat } \\
\text { Banka }\end{array}$ & $\begin{array}{l}\text { Panel Veri } \\
\text { Analizi }\end{array}$ & $\begin{array}{l}\text { Risk Ağırlıklı Varlıklar(+) } \\
\text { Mevduat Oranları (+) } \\
\text { Aktif Karlılık Oranı (+) } \\
\text { Aktif Kalitesi (-) }\end{array}$ \\
\hline $\begin{array}{l}\text { Minh ve Nga } \\
\text { (2018) }\end{array}$ & $\begin{array}{l}\text { Vietnam } \\
\text { 2008-2016 }\end{array}$ & $\begin{array}{l}\text { Borsada İşlem } \\
\text { Gören } 10 \\
\text { Ticari Banka }\end{array}$ & $\begin{array}{l}\text { Panel Veri } \\
\text { Analizi }\end{array}$ & $\begin{array}{l}\text { Mevduat Oranları (+) } \\
\text { Aktif Karlılık Oranı (+) } \\
\text { Özkaynak Karlııık Oranı (+) } \\
\text { Büyüklük (+) }\end{array}$ \\
\hline
\end{tabular}


Tablo 1. Literatür Özeti (Devamı)

\begin{tabular}{|c|c|c|c|c|}
\hline \multicolumn{5}{|l|}{ Ulusal Literatür } \\
\hline Yazar & Ülke- Dönem & Örneklem & Model & Sonuçlar \\
\hline $\begin{array}{l}\text { Büyüksalvarcı ve Abdioğlu } \\
\text { (2011) }\end{array}$ & $\begin{array}{l}\text { Türkiye } \\
\text { 2006-2010 }\end{array}$ & $\begin{array}{l}24 \text { Ticari } \\
\text { Banka }\end{array}$ & $\begin{array}{l}\text { Panel Veri } \\
\text { Analizi }\end{array}$ & $\begin{array}{l}\text { Kredi (-) } \\
\text { Özkaynak Karlıı̆ı̆ı (-) } \\
\text { Ve Finansal Kaldıraç (-) } \\
\text { Kredi Kayıp Karşılığı (+) } \\
\text { Aktif Karlılık (+) }\end{array}$ \\
\hline $\begin{array}{l}\text { Okuyan } \\
\text { (2013) }\end{array}$ & $\begin{array}{l}\text { Türkiye } \\
\text { 2002Ç1- } \\
2012 C ̧ 4\end{array}$ & 23 Banka & $\begin{array}{l}\text { Panel Veri } \\
\text { Analizi }\end{array}$ & $\begin{array}{l}\text { Risk (-) } \\
\text { Büyüklük (-) } \\
\text { Mevduat Oranı (-) } \\
\text { Kredi Oranı (-) } \\
\text { Ekonomik Büyüme (+) } \\
\text { Aktif Karlılık Oranı (+) }\end{array}$ \\
\hline $\begin{array}{l}\text { Reis ve Kötüoğlu } \\
\text { (2016) }\end{array}$ & $\begin{array}{l}\text { Türkiye } \\
\text { 2009-2015 } \\
\text { Çeyrek dönem }\end{array}$ & Türk Bankaları & $\begin{array}{l}\text { Regresyon } \\
\text { Analizi }\end{array}$ & $\begin{array}{l}\text { Aktif Karlıık Oranı (+) } \\
\text { Özkaynak Karlııı Oran (+) } \\
\text { Likidite (+) } \\
\text { Takibe Dönüşüm Oranı (+) }\end{array}$ \\
\hline $\begin{array}{l}\text { Koç ve Karahan } \\
\text { (2017) }\end{array}$ & $\begin{array}{l}\text { Türkiye } \\
\text { 2005-2015 }\end{array}$ & Türk Bankaları & $\begin{array}{l}\text { Panel Veri } \\
\text { Analizi }\end{array}$ & $\begin{array}{l}\text { Aktif Kalitesi (+) } \\
\text { Likidite (+) } \\
\text { Net Faiz Dışı Gelir (+) } \\
\text { Net Aktif Karlılığı (+) }\end{array}$ \\
\hline $\begin{array}{l}\text { Afşar ve Karaçayır } \\
\text { (2018) }\end{array}$ & $\begin{array}{l}\text { Türkiye } \\
\text { 2002-2017 } \\
\text { Çeyrek dönem }\end{array}$ & 9 Banka & $\begin{array}{l}\text { Panel Veri } \\
\text { Analizi }\end{array}$ & $\begin{array}{l}\text { Kredi Oranı (-) } \\
\text { Mevduat Oranı (-) } \\
\text { Aktif Büyüklüğ̈̈ (-) } \\
\text { Aktif Karlılık Oranı (+) }\end{array}$ \\
\hline $\begin{array}{l}\text { Hazar, Babuşçu, Tekindal ve } \\
\text { Köksal } \\
\text { (2018) }\end{array}$ & $\begin{array}{l}\text { Türkiye } \\
\text { 2004-2015 }\end{array}$ & $\begin{array}{l}\text { Mevduat } \\
\text { Toplama } \\
\text { Yetkisine } \\
\text { Sahip } 22 \\
\text { Banka } \\
\end{array}$ & Path Analiz & $\begin{array}{l}\text { Kredi (+) } \\
\text { Nazım Hesapları (+) } \\
\text { Menkul Kıymetler Cüzdanı (+) }\end{array}$ \\
\hline Özer ve Özer (2018) & $\begin{array}{l}\text { Türkiye } \\
\text { 2005-2017 }\end{array}$ & $\begin{array}{l}\text { Mevduat, } \\
\text { Kamu, Özel ve } \\
\text { Yabancı } \\
\text { Bankalar }\end{array}$ & EKK & $\begin{array}{l}\text { Büyüklük (+) } \\
\text { Finansal istikrar (+) } \\
\text { Likidite (+) } \\
\text { Varlık Yapısı (+) }\end{array}$ \\
\hline
\end{tabular}

Gerek ulusal gerekse uluslararası çalışmalarda sermaye yeterliliğini etkileyen faktörler ağırlıklı olarak banka büyüklüğü, karlılık durumu, aktif içindeki mevduat ve kredi payları olarak görülmektedir. Ancak söz konusu değişkenlerin yaratmış olduğu etkinin yönü ülkeden ülkeye değişiklik göstermektedir.

\section{Yöntem}

Türkiye Bankalar Birliği'nin 14.03.2019 tarihli bildirimine göre Türkiye'de 34 mevduat bankası hizmet vermektedir. Ancak söz konusu bankaların bazılarının çalışmanın inceleme dönemini kapsayan kesintisiz finansal verileri mevcut değildir. Bu nedenle bu çalışmada 2002-2017 döneminde Türkiye'de faaliyet göstermekte olan ve kesintisiz yıllık verilerine ulaşılabilen 19 mevduat bankası ele alınmıştır. Verileri kullanılan bankalar Tablo 2'de gösterilmiştir.

Çalışma, sermaye yeterlilik rasyosunu belirleyen faktörleri analiz etmeyi amaçlayan bir çalışma olup, kullanılan modelde sermaye yeterlilik rasyosu bağımlı değişken olarak ele alınmıştır. Aktif toplamı banka büyüklüğünün bir ölçütü olarak kabul edilmektedir. Büyük bankalar sektördeki itibarlarını sürdürmek için sermaye yeterlilik durumlarını daha yüksek tutma eğiliminde olabilmekte; ya da büyük bankalar risk yönetimini oldukça etkin bir şekilde sürdürebildikleri için dışarıdan sermaye ihtiyaçlarını küçük bankalara göre daha kolayca temin edebilmekte ve bu nedenle daha düşük sermaye yeterliliği oranına sahip olabilmektedir (Okuyan, 2013: 297). Bu anlamda banka büyüklügünün sermaye yeterlilik rasyosu üzerinde bir etkiye sahip olabileceği beklenmektedir. Aktif karlılı̆ı, bankalar için önemli bir karlılık ölçütüdür. Bankaların finansal performansına bağlı olarak aktif karlıı̆ı̆ının artması ile yasal özkaynaklarda artış olacak ve dolayısıyla sermaye 
yeterlilik rasyosunun artırması beklenecektir. Bir başka ifade ile Büyükşalvarcı ve Abdioğlu (2011)'nun da belirttiği üzere bankaların daha yüksek özsermayeye sahip olmalarının karlarını artırmalarına bağlı olduğu düşünülmektedir. Pek çok durumda daha yüksek bir getiri ise varlık riskinin artırılması ile mümkündür. Bu nedenle aktif karlılığının da sermaye yeterlilik rasyosunu etkileyebilecek bir faktör olduğu düşünülmektedir (Minh ve Nga, 2018; Koç ve Karahan 2017; Okuyan 2013). Bankaların üstlenmiş oldukları aracılık fonksiyonu gereği toplamış oldukları mevduatlar bilançolarındaki yükümlülüklerinin önemli bir kısmını oluşturmaktadır. Literatürde yer alan çalışmalara bakıldığında bir kısım yazarların bankalarda mevduat oranındaki artışın mevduat sahiplerinin haklarının korunması için özsermaye yeterliliğinin artışını da gerektirdiğini dolayısıyla iki değişken arasında pozitif bir ilişki olduğunu öne sürdüğünü (Abba vd. 2018); bir kısım yazarların ise mevduatlardaki azalışın toplam kaynak maliyetini arttırmasından ötürü bankanın daha çok sermayeye ihtiyaç duyduğunu dolayısıyla iki değiş̧en arasında negatif bir ilişki olduğunu öne sürdüğünü görmek mümkündür. Kredi oranı sermaye yeterlilik rasyosu üzerinde etkisi olduğu düşünülen bir başka değişkendir. Afşar ve Karaçayır (2018)'ın bulgularına göre kredi oranı ile sermaye yeterlilik rasyosu arasında negatif bir ilişki söz konusudur. Bu ilişkinin negatif olması bankaların sermayelerini temel fonksiyonu olan kredi verme işlemi dışında kullanmalarından kaynaklanmaktadır. Bununla birlikte kredi oranındaki artışın bankanın likiditesini düşürücü bir etki yaptığı, bunun da finansal başarısızlık riskini artırıcı etki yapacağı, bu nedenle kredi oranındaki artış ile sermaye yeterlilik rasyosunun da artırılacağını ileri süren çalışmalar da mevcuttur (Bateni, 2014). Bankaların sahip oldukları likit varlıklar özellikle kısa vadeli yükümlülüklerin yerine getirilmesinde varlıkların değer kaybına uğramaksızın hemen nakde çevrilme özelliklerinden ötürü önemli bir yere sahiptir. Angbazo (1997), bankaların likit varlıklarının artması ile birlikte likidite risklerinin düşeceğini, net faiz marjında daha düşük bir likidite primine yol açacağını belirtmiş; bundan dolayı bankaların likit varlık oranındaki artışın sermaye yeterlilik oranı üzerinde pozitif bir etki yaratacağını belirtmiştir. Faiz marjı aktif oranı finansal aracılık hizmetinde bankanın etkinliği hakkında fikir veren bir göstergedir. Bankaların getirisi ile sermayeleri arasındaki ilişki ise oldukça güçlüdür (Demirgüç-Kunt ve Huizinga, 2000). Dolayısıyla bankanın faiz marjının sermaye yeterlilik oranını doğrudan pozitif yönlü etkileyen bir faktör olması beklenmektedir. Bankaların risklilik durumlarına ilişkin önemli bir gösterge takipteki kredi oranıdır. Bankaların riskinin artmasının sermaye yeterlilik oranını negatif etkileyeceği yönünde çok sayıda bulgu literatürde yer almaktadır. Takipteki kredi oranının düşük olması banka için daha az kayıp demektir. Dolayısıyla takipteki kredi oranı düştükçe bankanın sermaye yeterlilik oranının artması beklenmektedir (Irawan ve Anggona, 2015).

Tablo 2. Çalışmanın Örneklemini Oluşturan Bankalar

\begin{tabular}{||l|l|l|l||}
\hline Sıra No & Banka Adı & Sıra No & Banka Adı \\
\hline \hline 1 & Akbank & 11 & Şekerbank \\
2 & Alternatif Bank & 12 & Turkishbank \\
3 & Anadolu Bank & 13 & TEB \\
4 & Arap Türk Bank & 14 & Ziraat Bank \\
5 & Bank Mellat & 15 & Garanti Bank \\
6 & Citi Bank & 16 & Halkbank \\
7 & Denizbank & 17 & İş Bankası \\
8 & Habib Bank & 18 & Vakıflar Bankası \\
9 & HSBC Bank & 19 & Yapı Kredi Bankası \\
10 & QNB Finansbank & & \\
& & & \\
\hline
\end{tabular}

Tablo 3'te hesaplanma yöntemleri ve modellerde kullanılan kısaltmalarının yer verildiği bağımlı değişken ve bağımsız değişkenler gösterilmiştir. Ele alınan değişkenlere ait veriler Türkiye Bankalar Birliği Veri Sorgulama Sistemi'nden temin edilmiştir.

Çalışma, yatay kesit ve zaman serisi verilerini ihtiva eden bir panel veri niteliğindedir. Bu nedenle bağımlı değişken olarak tanımlanan sermaye yeterlilik rasyosunu etkilediği düşünülen değişkenlerin tespiti panel veri analizi ile gerçekleştirilmiştir. 
Tablo 3. Çalışmada Kullanılan Değişkenler ve Hesaplanma Yöntemleri

\begin{tabular}{|l|l|c|c|}
\hline & Değişkenler & $\begin{array}{c}\text { Değişken } \\
\text { Kısaltmaları }\end{array}$ & \multicolumn{1}{c|}{ Hesaplanma Yöntemi } \\
\hline 1 & Sermaye Yeterlilik Rasyosu & SYR & $\begin{array}{c}\text { Özkaynak / (Kredi+Piyasa+Operasyonel Riske } \\
\text { Esas Tutar) }\end{array}$ \\
\hline 2 & Aktif Toplamı & A & Bilanço Toplam Aktif Tutarı \\
\hline 3 & Mevduat Aktif Oranı & MA & Toplam Mevduat / Toplam Aktif \\
\hline 4 & Kredi Aktif Oranı & KA & Toplam Kredi / Toplam Aktif \\
\hline 5 & Aktif Karııı̆ı & ROA & Dönem Karı/ Toplam Aktif \\
\hline 6 & Likit Aktif Oranı & LA & Likit Varlık Toplamı / Toplam Aktif \\
\hline 7 & Faiz Marjı & FM & (Faiz Geliri - Faiz Gideri)/Toplam Aktif \\
\hline 8 & Takipteki Kredi Oranı & TKTK & Takipteki Kredi / Toplam Kredi \\
\hline
\end{tabular}

Yıllık verilerin kullanıldığı analizde gözlem sayısı, 19 bankaya ait toplam 16 yıl verisi ile 304'tür. Değişkenlere ilişkin tanımlayıcı istatistiklere Tablo 4'te yer verilmiştir. Bankaların büyüklük göstergesi olarak aktif büyüklüğü ele alınmıştır. Örneklemde en yüksek aktif büyüklüğü $434.000 .000 \mathrm{TL}$, en düşük aktif büyüklüğü 25.564 TL, ortalama aktif büyüklüğü 54.955.498-TL'dir. Diğer tüm değişkenlerin oransal bir ifade ile ele alınmış olması, banka büyüklüğünün de logaritmasını alarak modele dahil etmeyi gerektirmiştir. 20022017 döneminde bankaların ortalama sermaye yeterlilik rasyoları 24,8'dir. Söz konusu değer, Basel kriterlerinin öngürmüş olduğu standart rasyo değerinin oldukça üzerindedir. Bununla birlikte en düşük sermaye yeterlilik rasyosu olarak görülen 7,2 değeri 2005 yılına tekabül etmektedir. Günümüzde her ne kadar Basel kriterleri \%8 oranında bir sermaye yeterlilik rasyosunu makul ve sürdürülebilir olarak görse de BDDK 2006 yılından beri \%12'lik bir oranı hedeflemekte ve uygulamaktadır. Türkiye' de ele alınan dönem itibariyle takipteki kredilerin toplam kredilere oranının ortalama değeri $0.08^{\prime}$ dir.

Tablo 4. Tanımlayıcı İstatistik Tablosu

\begin{tabular}{|l|c|c|c|c|c|c|c|c|}
\hline & SYR & LOGA & MA & KA & ROA & LA & FM & TKTK \\
\hline Ortalama & 24,83 & 16,26 & 0,59 & 0,48 & 0,03 & 0,92 & 0,05 & 0,08 \\
\hline En Yüksek & 109,20 & 19.89 & 0,88 & 0,78 & 0,40 & 0,99 & 0,13 & 1,15 \\
\hline En Az & 7,2 & 10,14 & 0,03 & 0,007 & 0,00 & 0,66 & $-0,03$ & 0,00 \\
\hline Standart Sapma & 19,13 & 2,29 & 0,17 & 0,18 & 0,05 & 0,06 & 0,01 & 0,15 \\
\hline Gözlem SayıSI & 304 & 304 & 304 & 304 & 304 & 304 & 304 & 304 \\
\hline
\end{tabular}

\section{Araştırma Bulguları}

Çalışmada sermaye yeterlilik rasyosunu etkilediği düşülen bağımsız değişkenler arasında çoklu doğrusal bağlantı olup olmadığı Spearman Korelasyon testi ile sınanmıştır. Elde edilen bulgular Tablo 5'te gösterildiği gibidir. Korelasyon analizi sonuçlarına göre değişkenler arasında yüksek korelasyon olmadığı görülmüştür.

Sermaye yeterlilik rasyosunu etkileyen faktörleri tespit etmek amacıyla aşağıdaki model oluşturulmuştur;

$S Y R_{i t}=\alpha_{0}+\beta_{1} L O G A_{i t}+\beta_{2} M A_{i t}+\beta_{3} K A_{i t}+\beta_{4} R O A_{i t}+\beta_{5} L A_{i t}+\beta_{6} F M_{i t}+\beta_{7} T K T K_{i t}+u_{i t}$

Ele alınan modelde i toplam 19 bankanın dahil edildiği yatay kesit sayısını ( $i=1,2,3 \ldots . .19), \mathrm{t}$ 2002-2017 dönemi olarak belirtilen dönem sayısını ( $\mathrm{t}=1,2,3 \ldots 16)$ göstermektedir. Analiz aşamasında sırasıyla yatay kesit bağımlılık analizi, birim kök sınaması, uygun modelin seçilmesi, modelde otokorelasyon ve değişen varyansın tespiti ve son olarak modelin dirençli tahmin ediciler ile yeniden tahminlenmesi gerçekleştirilmiştir. 
Tablo 5. Korelasyon Analizi Sonuçları

\begin{tabular}{|l|c|c|c|c|c|c|c|}
\hline & LOGA & MA & KA & ROA & LA & FM & TKTK \\
\hline LOGA & 1 & 0,554 & 0,536 & $-0,431$ & 0,160 & $-0,333$ & $-0,307$ \\
\hline MAK & 0,554 & 1 & 0,166 & $-0,301$ & $-0,009$ & $-0,141$ & $-0,216$ \\
\hline KA & 0,536 & 0,166 & 1 & $-0,331$ & 0,363 & $-0,190$ & $-0,521$ \\
\hline ROA & $-0,431$ & $-0,301$ & $-0,331$ & 1 & $-0,155$ & 0,066 & $0-282$ \\
\hline LA & 0,160 & $-0,009$ & 0,363 & $-0,155$ & 1 & $-0,115$ & $-0,115$ \\
\hline FM & $-0,333$ & $-0,141$ & $-0,190$ & 0,066 & $-0,115$ & 1 & 0,190 \\
\hline TKTK & $-0,307$ & $-0,216$ & $-0,521$ & 0,282 & $-0,115$ & 0,190 & 1 \\
\hline
\end{tabular}

Çalışmada zaman boyutu yatay kesit boyutundan küçük olduğu için (Peseran, 2004) CDLMadj test ile yatay kesit bağımlılığı sınanmıştır. $\mathrm{H}_{0}$ hipotezinin yatay kesit bağımlılı̆ının olmadığıı belirttiği testte analize dahil edilen değişkenlerinin tümünün olasılık değerlerinin 0,05 in altında kaldığı, dolayısıyla $\mathrm{H}_{0}$ hipotezinin reddedilerek serilerin tümünde yatay kesit bağımlılığı olduğu sonucuna ulaşılmıştır.

Tablo 6. Yatay Kesit Bağımlılık Test Sonuçları

\begin{tabular}{|l|l|c|c|}
\hline Test & Değişkenler & İstatistik & Olasılık \\
\hline \multirow{5}{*}{ CDLMadj (PUY, 2008) } & SYR & 7,410 & 0,000 \\
\cline { 2 - 4 } & LOG A & 10,622 & 0,000 \\
\cline { 2 - 4 } & MA & 8,228 & 0,000 \\
\cline { 2 - 4 } & KA & 12,179 & 0,000 \\
\cline { 2 - 4 } & ROA & 2,879 & 0,002 \\
\cline { 2 - 4 } & LA & 13,629 & 0,000 \\
\cline { 2 - 4 } & FM & 2,096 & 0,018 \\
\cline { 2 - 4 } & TKTK & 4,714 & 0,000 \\
\hline
\end{tabular}

Panel veri analizlerinde değişkenler arasında sahte ilişkilere neden olunmaması için değişkenlerin durağan olması gerekmektedir (Korkmaz, 2010: 100). Bu nedenle bir sonraki aşamada panel veri analizinin yapılabilmesi için serilerin durağanlık durumu test edilmiştir. Serilerin durağan olup olmadığı bir başka ifade ile birim kök içerip içermediğini tespit etmek amacıyla yatay kesit bağımlılığını dikkate alan ikinci nesil birim kök testlerinden Hadri-Kurozumi (2012) birim kök testi uygulanmıştır. Hadri-Kurozumi (2012) testi sonuçlarına göre yatay kesit bağımlılığı durumunda $Z^{S P C}$, yatay kesit bağımlılığı olmadığı durumda ise $Z^{\mathrm{LA}}$ değerleri dikkate alınmaktadır. Yatay kesit bağımlıık analizi sonuçlarına göre serilerin tümünde yatay kesit bağımlılığı söz konusu olduğu için $Z^{\text {SPC }}$ test sonuçları dikkate alınmıştır. Her bir değişkene ait serilere uygulanan, $\mathrm{H}_{0}$ hipotezinin birim kök yoktur şeklinde ifade edildiği Hadri-Kurozumi birim kök test sonuçları Tablo 7'de özetlendiği gibidir. Buna göre, değişkenlerin tümünün seviyede durağan olduğu; birim kök içermediği tespit edilmiştir.

Tablo 7. Hadri-Kurozumi (2012) Birim Kök Test Sonuçları

\begin{tabular}{|l|l|l|c|c|}
\hline Seviye & Değişkenler & Test & İstatistik & Olasılık \\
\hline $\mathrm{I}(0)$ & SYR & $\mathrm{Z}^{\mathrm{SPC}}$ & $-0,87$ & 0,80 \\
\hline $\mathrm{I}(0)$ & LogA & $\mathrm{Z}^{\mathrm{SPC}}$ & $-0,25$ & 0,60 \\
\hline $\mathrm{I}(0)$ & MA & $\mathrm{Z}^{\mathrm{SPC}}$ & 1,21 & 0,11 \\
\hline $\mathrm{I}(0)$ & KA & $\mathrm{Z}^{\mathrm{SPC}}$ & $-0,69$ & 0,75 \\
\hline $\mathrm{I}(0)$ & ROA & $\mathrm{Z}^{\mathrm{SPC}}$ & $-0,34$ & 0,63 \\
\hline $\mathrm{I}(0)$ & LA & $\mathrm{Z}^{\mathrm{SPC}}$ & $-1,84$ & 0,96 \\
\hline $\mathrm{I}(0)$ & FM & $\mathrm{Z}^{\mathrm{SPC}}$ & 0,66 & 0,25 \\
\hline $\mathrm{I}(0)$ & TKTK & $\mathrm{Z}^{\mathrm{SPC}}$ & $-0,39$ & 0,65 \\
\hline
\end{tabular}


Analizin son aşamasında Panel veri analizi önce havuzlanmış en küçük kareler varsayımı ile sonrasında sabit ekiler ve rassal etkiler varsayımları ile gerçekleştirilmiştir (Tablo 8). Panel veri modellerinde tahminciler arasında seçim yapmak için Hausman Test kullanılmaktadır. Hausman testinde temel hipotez "açıklayıcı değişkenler ve birim (zaman) etki arasında korelasyon yoktur" şeklindedir. Bu durumda her iki tahminci de tutarlı olduğundan sabit ve rassal etkiler tahmincileri arasındaki farkın çok küçük olacağı beklenmektedir. Bu durumda rassal etkiler tahmincisi daha etkin olduğundan kullanımı daha uygun olmaktadır (Yerdelen Tatoğlu, 2016: 185). Tablo 9'da yer alan bulgulara göre olasılık değeri 0,05 değerinin altında olduğu için $(p=0,000)$ Sabit etkiler model sonuçlarının geçerli olduğuna karar verilmiştir.

Tablo 8. Panel Havuzlanmış EKK, Sabit ve Rassal Etkiler Test Sonuçları

\begin{tabular}{|l|c|c|c|c|c|c|}
\hline & \multicolumn{2}{|c|}{ Havuzlanmış EKK } & \multicolumn{2}{c|}{ Sabit Etkiler } & \multicolumn{2}{c|}{ Rassal Etkiler } \\
\hline Değişkenler & Katsayı & Olasılık & Katsayı & Olasılık & Katsayı & Olasılık \\
\hline C & 19,03234 & 0,056 & 24,66151 & 0,041 & 31,57467 & 0,002 \\
\hline LogA & $-0,02553$ & 0,942 & 1,484891 & 0,118 & $-0,27982$ & 0,555 \\
\hline MA & $-41,9234$ & 0,000 & $-30,014$ & 0,000 & $-37,8285$ & 0,000 \\
\hline KA & $-48,3777$ & 0,000 & $-33,1379$ & 0,000 & $-39,1304$ & 0,000 \\
\hline ROA & 8,005286 & 0,510 & $-11,274$ & 0,354 & $-0,84868$ & 0,941 \\
\hline LA & 46,90105 & 0,000 & $-3,65821$ & 0,767 & 29,3882 & 0,002 \\
\hline FM & 162,48 & 0,000 & 227,5024 & 0,000 & 190,418 & 0,000 \\
\hline TKTK & 39,88701 & 0,000 & 37,45181 & 0,000 & 38,50602 & 0,000 \\
\hline
\end{tabular}

Tablo 9. Hausman Test Sonucu

\begin{tabular}{|l|c|c|c|}
\hline & Ki-Kare Ist. & Ser. Der. & Olasilık \\
\hline Hausman Test & 34,49263 & 7 & 0,000 \\
\hline
\end{tabular}

Uygulanan modelin otokorelasyon ve değişen varyans sorunu içerip içermediğini bakılmıştır. Otokorelasyon sınamasında Durbin Watson katsayısı 1,05, Baltagi Wu LBI değeri 1,26 olarak bulunmuştur. \%5 anlamlılık düzeyinde Durbin Watson Kritik değerleri ile karşılaştırıldı̆̆ında elde edilen değerin kritik değerden küçük olmasından ötürü otokorelasyonun var olduğu görülmüştür. Değişen varyans sınaması Wald test ile yapılmıştır. Wald test sonucu $(p=0,000) \% 5$ anlamlılık düzeyinde serinin değişen varyans içerdiğini göstermiştir. Bunun üzerine otokorelasyon ve değişen varyans içeren model, $\mathrm{N}>\mathrm{T}$ olması ve Hausman test sonucuna göre uygun modelin sabit etkiler modelinin geçerli model olarak tespit edilmesinden ötürü DriscollKraay dirençli tahmin edicisi ile yeniden tahmin edilmiştir. Driscoll ve Kraay (1998) standart parametrik olmayan zaman serisi kovaryans matris tahmincilerinin uzamsal ve dönemsel korelasyonun tüm formları için dirençli olabilecek şekilde geliştirilebileceğini göstermiştir. Bu tahminci, büyük $T$ ve $N$ durumunda bile heteroskedastisite varlığında tutarlı, uzamsal ve dönemsel korelasyonun genel formlarında dirençli standart hatalar üretmektedir (Yerdelen Tatoğlu, 2016: 276). Elde edilen bulgular Tablo 10'da özetlenmiştir.

Tablo 10. Panel Veri Analizi Sonuçları

\begin{tabular}{|l|l|c|c|c|c|c|c|c|c|}
\hline & & LOGA & MA & KA & ROA & LA & FM & TKTK & SABiT \\
\hline \multirow{2}{*}{$\begin{array}{l}\text { DiRENÇLi } \\
\text { TAHMiN } \\
\text { EDici }\end{array}$} & Katsayı & 1,48 & $-30,01$ & $-33,13$ & $-11,27$ & $-3,65$ & 227,50 & 37,45 & 24,66 \\
\cline { 2 - 10 } & Std. Hata & 0,54 & 3,38 & 5,03 & 9,71 & 13,48 & 28,79 & 13,69 & 12,17 \\
\cline { 2 - 10 } & t-ist. & 2,70 & $-8,86$ & $-6,58$ & $-1,16$ & $-0,27$ & 7,90 & 2,73 & 2,03 \\
\cline { 2 - 10 } & Olasılık & 0,01 & 0,00 & 0,00 & 0,26 & 0,79 & 0,00 & 0,01 & 0,06 \\
\hline
\end{tabular}


Tablo 10'da sunulmuş olan sonuçlara göre \%5 anlamlılık düzeyinde bağımlı değişken SYR'nin LOGA, MA, KA, FM ve TKTK bağımsız değişkenleri ile arasında anlamlı bir ilişki olduğu; bir başka ifade ile sermaye yeterlilik rasyosunun bankaların toplam aktif büyüklüğü, mevduat/toplam aktif oranı, kredi/toplam aktif oranı, faiz marjı ve takipteki kredi/toplam kredi değişkenlerinde değişimden etkilendiği tespit edilmiştir. Bu etkinin yönünün toplam aktif büyüklüğü, faiz marjı ve takipteki kredi/toplam kredi oranları için pozitif iken; mevduat/toplam aktif ve kredi/ toplam aktif oranları için negatif olduğu tespit edilmiştir. Bununla birlikte modelin $f$ istatistik olasılık değeri \%99 güven düzeyinde anlamlı olduğu ve bağımsız değişkenlerin bağımlı değişkendeki değişimin \%63,50'sini $\left(R^{2}\right)$ açıkladığı belirlenmiştir.

\section{Sonuç}

İçinde bulunduğumuz yüzyılda gerek reel, gerekse finansal anlamda ülkelerin sürekli bir etkileşim içinde olmaları özellikle ülkelerin bankacılık sektörünün sağlamlaştırılması için ortak girişimleri gerekli kılmıştır. Basel I standartları ile başlayan düzenlemeler bu anlamda önemli bir ilerleme kaydedilmesini sağlamıştır. Basel kriterleri ile özellikle bankaların sermaye yeterlilik rasyoları üzerinde durulmuştur. Sermaye yeterlilik rasyosu bankalarda karlılık ve risklilik durumuna ilişkin önemli gösterge olarak kabul edilmektedir. Yüksek sermaye yeterlilik rasyosu riski düşürmekte ancak bununla birlikte yüksek karlılıktan da vazgeçmeyi gerektirmekte iken düşük sermaye yeterlilik rasyosu yüksek karlılığa ulaşmak için bankalara imkan sağlamakta ancak yüksek riski de beraberinde getirmektedir. Bu nedenle bankaların kendi dinamiklerine göre doğru bir sermaye yeterlilik rasyosu belirlemeleri ve sürdürmeleri önem arz etmektedir. Bu çalışma, bu anlamda bankaların sermaye yeterlilik rasyosunu etkileyen faktörleri ortaya koymayı amaçlamıştır. 2002-2017 dönemi Türkiye'de faaliyet göstermekte olan mevduat bankaları örneklemi üzerinde yapılan araştırma neticesinde mevduat bankalarının sermaye yeterlilik rasyosunu etkileyen faktörlerin bankaların toplam aktif büyüklüğü, mevduat/toplam aktif oranı, kredi/toplam aktif oranı, faiz marjı ve takipteki kredi/toplam kredi oranları olduğu tespit edilmiştir.

Bankaların büyüklükleri, faiz marjı ve takipteki kredi/toplam kredi oranları ile sermaye yeterlilik rasyoları arasında pozitif yönlü bir ilişkinin, mevduat/toplam aktif oranı, kredi/toplam aktif oranı ile sermaye yeterlilik rasyoları arasında negatif yönlü bir ilişkinin tespit edilmiş olması bankaların aktif büyükleri, faiz marjı ve takipteki kredi/toplam kredi oranları arttıkça sermaye yeterlilik rasyosunun da arttığını; mevduat/toplam aktif oranı, kredi/toplam aktif oranı arttıkça sermaye yeterlilik rasyosunun düştüğünü göstermektedir. Bununla birlikte aktif karlııı̆ı ve likit aktif oranı değişkenleri ile sermaye yeterlilik rasyosu arasında anlamlı bir ilişki bulunamamıştır.

Uluslararası literatürde banka büyüklüğü ile sermaye yeterlilik rasyosu arasında ağırlıklı olarak negatif yönlü ilişki bir iliş̧ki tespit edilmiştir ancak bununla birlikte ilişkinin yönünü pozitif bulan çalışmalar da mevcuttur (Gropp ve Heider, 2010). ilişkinin negatif olması büyük bankaların kendilerini batamayacak kadar büyük olarak görmeleri ile ilişkilendirilmiştir. Bankalar batamayacak kadar büyük olmanın verdiği güven ile düşük sermaye yeterlilik rasyosu ile faaliyetlerini sürmektedir. Bu çalışmada banka büyüklüğü ile sermaye yeterlilik rasyosu arasındaki pozitif ilişki, ele alınan örneklem itibariyle bankaların büyüklüklerinin artması ile birlikte beklenenin aksine kendilerini batamayacak kadar büyük görmediklerini, daha temkinli ve daha intiyatlı davrandıklarını göstermektedir. Türk bankacılık sektöründe banka büyüklüğü arttıkça sermaye yeterlilik rasyosunun da artması büyük bankaların sektördeki itibarlarını sürdürmek için sermaye yeterlilik rasyolarını da arttırmaları ile açıklanabilir. Mevduat/toplam aktif oranı ve kredi/toplam aktif oranı ile sermaye yeterlilik rasyosu arasında negatif ilişki tespit edilmiştir. Ele alınan iki değişken, bankaların finansal aracılık hizmeti göstergesi olarak da değerlendirilebilir. Bu açıdan bakıldığında bankaların finansal aracılık hizmeti ile sermaye yeterlilik rasyosu arasında negatif bir ilişki tespit edilmiştir. Toplam aktif başına düşen gerek kredi gerekse mevduat tutarındaki artış neticesinde bankalar sermaye yeterlilik rasyolarını düşürmektedir. Bu bankaların finansal aracılık faaliyet hacimlerine güvenerek hareket ettiklerinin bir göstergesi olarak düşünülebilir. Faiz marjı ile sermaye yeterlilik rasyosu arasındaki pozitif ilişki, artan faiz marjı ile bankalarda dağıtılmayan kar tutarının artması ve dağıtılmayan karların bankaların sermayelerine eklenmesi ile daha yüksek bir sermaye yeterlilik rasyosuna sahip olmalarına sebep olması ile açıklanabilmektedir. Takipteki kredi/toplam kredi oranı ile sermaye yeterlilik rasyosu arasında pozitif bir ilişki olduğu görülmüştür. Takipteki 
kredi/toplam kredi oranının yüksek olması bankaların yüksek finansal risk içerisinde olduğunu göstermektedir. Kullandırılan kredilerin geri ödenmeme ihtimalinin yüksek olması olarak da ifade edilebilecek olan bu durum bankanın finansal yapısının zayıflamasına sebep olmakta ve yükselen kredi riskine karşlık özsermaye tutarlarını artırmaya yönlendirmektedir.

Türk bankacılık sektörü tecrübe ettiği finansal krizler sonrası finansal sistemin en önemli öğesi olan bankalara yönelik çok sayıda yapısal düzenleme gerçekleştirmiştir. Basel kriterlerinin çok üzerinde bir ortalama sermaye yeterlilik rasyosuna sahip olan bankalar için gerçekleştirilen analiz Türkiye'de bankaların batamayacak kadar büyük düşüncesi ile hareket etmediğini, artan takipteki kredi oranı nedeniyle artan finansal riske ilişkin olarak özsermaye unsurlarında artış sağlayarak güvenli bir sermaye yapısını koruduğunu ancak finansal aracılık hizmeti ile artan kredi ve mevduatlara güvenerek hareket ettiklerini göstermektedir. Türk bankacılık sisteminin, artan kredi hacmi içinde göz ardı edilemeyecek büyüklükteki takipteki kredilerin yarattığı risk ve mevduatlardaki artışı sağlayan banka mevduat müşterilerinin bankaya olan güven duygusunu yitirmesinin beraberinde getireceği risk unsurlarını dikkate alması gerekmektedir.

\section{Son Notlar}

1. Bu çalışma 18-20 Nisan 2019 tarihinde İzmir Demokrasi Üniversitesi iiBF tarafından düzenlenen 4.Lisansüstü İ̧letme Öğrencileri Sempozyumunda sözlü olarak sunulmuş ve gerekli düzeltmeler yapılmışır.

\section{Kaynaklar}

Abba, G. O., Okwa, E., Soje, B., \& Aikpitanyi, L. N (2018). Determinants of capital adequacy ratio of money banks in Nigeria. Journal of Accounting \& Marketing, 7(2), 1-7.

Abusharbeh, M. T., Triyuwono, I., İsmail, M. R., \& Aulia, F. (2013), Determinants of capital adequacy ratio (car) in Indonesian Islamic commercial banks. Global Review of Accounting and Finance, 4(1), 159-170.

Acar Balaylar, N., \& Özdemir, M. O. (2018). Türkiye'de yerli mevduat bankalarında sermaye yeterliliği ve karlılık ilişkisi. Muhasebe ve Denetime Bakış Dergisi, 18(54), 57-76.

Afşar, A., \& Karaçayır, E. (2018). Türk bankacılık sektöründe sermaye yeterlilik oranının belirleyicileri. Anadolu Üniversitesi Sosyal Bilimler Dergisi, 18(2), 149-159.

Ahmad, R., Ariff, M., \& Skully, M. (2008). The determinants of bank capital ratios in a developing economy. Asia-Pacific Financial Markets, 15(3-4), 255-272.

Aktaş, R., Açıkalın, S., Bakın, B., \& Çelik, G. (2015). The determinants of banks' capital adequacy ratio: Some evidence from South Eastern European countries. Journal of Economics and Behavioral Studies, 7(1), 79-88.

Alajmi, M., \& Alqasem, K. (2015). Determinants of capital adequacy ratio in Kuwaiti banks. Journal of Governance and Regulation, 4(4), 315-322.

Al-Tamimi, K. A. M., \& Obeidat, S. F. (2013). Determinants of capital adequacy in commercial banks of Jordan an empirical study. International Journal of Academic Research in Economics and Management Sciences, 2(4), 4458.

Aydın, H. İ., \& Yalçınkaya, Ö. (2017). Ar-Ge yatıımlarının toplam faktör verimliliği üzerindeki etkileri: OECD ülkeleri üzerinde panel veri analizi (1994-2014). Pamukkale Üniversitesi Sosyal Bilimler Enstitüsü Dergisi, 26, 178-196.

Aysan, A. F., \& Ceyhan, Ş. P. (2008). What determines the banking sector performance in globalized financial markets? The case of Turkey. Physca A, 387, 1593-1602.

Bankacılık Düzenleme ve Denetleme Kurulu (2010). "Sorularla Basel III", Erişim Adresi http://www.bddk.org.tr/WebSitesi/turkce/Raporlar/Finansal_Piyasalar_Raporlari/8469fpr.pdf (Erişim Tarihi, 15.12.2018).

Bateni, L., Vakilifard, H., \& Asghari, F. (2014). The influential factors on capital adequacy ratio in Iranian banks. International Journal of Economicsand Finance, 6(11), 108-116.

Bokhari, I. A., SyedMuhamad \& Sultan, K. (2012). Determinants of capital adequacy ratio in banking sector: An empirical analysis from Pakistan. Academy of Contemporary Research Journal, 2(1), 1-9. 
Büyükşalvarcı, A., \& Abdioğlu, H. (2011). Determinants of capital adequacy ratio in Turkish banks: A panel data analysis. African Journal of Business Management, 5(27), 11199-11209.

Demirgüç-Kunt A., \& Huizinga, H. (2000). Financial structure and bank profitability. World Bank Policy Research Working Paper No. 2430.

Dreca, N. (2013). Determinants of capital adequacy ratio in selected Bosnian banks. Dumlupınar Üniversitesi Sosyal Bilimler Dergisi, Özel Sayı, 149-162.

El-Ansary, O. A., \& Hafez, H. M. (2015). Determinants of capital adequacy ratio: An empirical study on Egyptian banks. Corporate Ownership \& Control, 13(1), 806-816.

Erdoğan, A. (2014). Basel kriterlerinin bankacılık sektörüne etkisi ve Türkiye'de bankacılık sektörünün Basel kriterlerine uyum süreci. Trakya Üniversitesi Sosyal Bilimler Dergisi, 16(1), 133-174.

Ersoy, H. (2011). Türk bankacılık sisteminde sermaye yeterliliği ve Basel standartları. İstanbul Aydın Üniversitesi Dergisi, 3(10), 53-72.

Gropp, R., \& Heider, F. (2010). The determinants of bank capital structure. Review of Finance, 14(4), 587-622.

Gürel, E., Bulgurcu G., \& Demir E. B. (2012). Basel II kriterleri. Bankacılık ve Sigortacılık Araştırma Dergisi, 1(3-4),16-28.

Hassan, M. K., \& Bashir, M. A. (2003). Determinants of Islamic banking profitability. ERF Paper Presented at Economic Research Forum 10th Annual Conference, 1-31.

Hazar, A., Babuşçu, Ş., Tekindal, M. A., \& Köksal, M. O. (2018). Bankacılık sektöründe sermaye yeterliliği rasyosunu belirleyen risklerin analizi. Uluslararası iktisadi ve Idari Incelemeler Dergisi, 20(20), 135-150.

https://home.kpmg/tr/tr/home/gorusler/2018/02/sektorel-bakis-2018.html (Erişim Tarihi: 15.12.2018).

Irawan, K., \& Anggono, A. H. (2015). A study of capital adequacy ratio and its determinants in Indonesian banks: A panel data analysis. International Journal of Management and Applied Science, 1(9), 98-101.

Kılcı, E. N. (2019). Türk bankacılık sektöründe 1980-2017 döneminde sermaye yeterliliği ve karlılık arasındaki ilişkinin analizi: Fourier Yaklaşımı. Dumlupınar Üniversitesi Sosyal Bilimler Dergisi, 59, 61-73.

Kleff, V., \& Weber, M. (2008). How do banks determine capital? Evidence from Germain. German Economic Review, 9(3), 354-372.

Klepczarek, E. (2015). Determinants of European banks' capital adequacy. Comparative Economic Research, 18(4), 8199.

Koç, Y. D., \& Karahan, F. (2017). Türk bankacılık sektöründe finansal sağlamlığın belirleyicileri. International Journal of Academic Value Studies, 3(15), 148-153.

Korkmaz, T. (2010). FVFM'nin IMKB ulusal 100 endeksindeki geçerliliğinin panel veri analizi ile test edilmesi. İstanbul Üniversitesi İşletme Fakültesi Dergisi, 30(1), 95-105.

Masood, U., \& Ansari, S. (2016). Determinants of capital adequacy ratio a perspective from Pakistani banking sector. International Journal of Economics, Commerce and Management, 4(7), 247-273.

Mekonnen, Y. (2015). Determinants of capital adequacy of Ethiopia commercial banks. European Scientific Journal, 11(25), 315-331.

Minh, T., \& Nga, L. P. (2018). Factors affecting the capital adequacy ratio (car) of the commercial banks listed on the Vietnam stock market. Journal of Business Management and Economics, 6(4), 19-23.

Mizrahi, R., \& Kandemir, i. (2018). Türk bankacılık sektörünün Basel III kriterleri perspektifinde değerlendirilmesi. Muhasebe ve Finans incelemeleri Dergisi, 1(2), 148-161.

Moussa, M., Aymen B. (2018). Determinants of bank capital: Case of Tunisia. Journal of Applied Finance \& Banking, 8(2), $1-15$.

Nuviyanti, N., \& Anggono, A. H. (2014). Determinants of capital adequacy ratio (car) in 19 commercial banks (case study: period 2008-2013). Journal of Business and Management, 3(7), 752-764.

Okuyan, H. A. (2013). Türk bankacılık sektöründe sermaye yapısı. Ege Akademik Bakış, 13(3) 295-302.

Özer A., \& Özer N. (2018). Türk bankacılık sektöründe sermaye yapısının belirleyicileri. International Congress on Political, Economic and Social Studies Proceedings, 180-194.

Pesaran, H. (2004). General diagnostic testsfor cross section dependence in panels. Cambridge Working Papers in Economics Working Paper, 435.

Pesaran, H. (2007). A Simple panel unit root test in the presence of cross section dependence. Journal of Applied Econometrics, 22(2), 265-312. 
Pesaran, H., \& Yamagata, T. (2008). Testing slope homogeneity in large panels. Journal of Econometrics, 142, 50-93.

Polat, A., \& Al-Khalaf, H. (2014). What determines capital adequacy in the banking system of Kingdom of Saudi Arabia? A panel data analysis on Tadawul banks. Journal of Applied Finance \& Banking, 4(5), 27-43.

Reis, G., \& Kötüoğlu, R. (2016). Türk bankacılık sektörünün sermaye yeterliliği davranışı. Yönetim ve Ekonomi Araştırmaları Dergisi, 14(3), 101-110.

Romdhane, M. (2012). The determinants of banks' capital ratio in developing countries: Empirical evidence fromTunisia. http://ssrn.com/abstract=1688325, 1-20.

Sayılgan, G., \& Yıldırım, O. (2009). Determinants of profitability in Turkish banking sector: 2002-2007. International Research Journal of Finance and Economists, 28, 208-214.

Shingjergji, A., \& Hyseni, M. (2015). The determinants of the capital adequacy ratio in the Albanian banking system during 2007 - 2014. International Journal of Economics, Commerce and Management, 3(1), 1-10.

Thoa, P. T., \& Anh, N. N. (2017). The determinants of capital adequacy ratio: The case of the Vietnamese banking system in the period 2011-2015. VNU Journal of Science: Economics and Business, 33(2), 49-58.

Tunay, K. B, \& Silpar, A. M. (2006). Türk ticari bankacılık sektöründe karlılığa dayalı performans analizi-I. TBB Araştırma Tebliğleri Serisi, 2006/I.

Turguttopbaş, N. (2017). Türk bankacılık sektörü sermaye yeterliliğinin ekonomik konjonktürle ilişkisi. Uluslararası Katılımlı 21. Finans Sempozyumu, 18 - 21 Ekim 2017, Balıkesir, 749-761.

Yüksel Mermod, A., \& Ceran, M. (2011). Basel III doğrultusunda bankacılık riskleri ve sermaye yeterliliği: Türk bankacılık sektörü üzerine karşılaştırmalı bir analiz. Finansal Araştırmalar ve Çalışmalar Dergisi, 2(4), 29-38. 
This Page Intentionally Left Blank 